\title{
Production strategy development for an energy company based on SADT
}

\author{
Anna Minnullina ${ }^{1, *}$, Ruslan Minnullin ${ }^{1}$, Anna Kopytova $^{1}$, and Elena Savoskina ${ }^{2}$ \\ ${ }^{1}$ Industrial University of Tyumen, Volodarskogo St., 38, Tyumen, 625000, Russia \\ ${ }^{2}$ Samara State Technical University, Molodogvardeyskaya street, 244, Samara, Russia
}

\begin{abstract}
The article presents an algorithm for choosing the type of production strategy and its development in a company performed by a formed working group. In order to clearly reflect the relationship between the production strategy under developed and other functional strategies of companies and to eliminate all kinds of errors that many developers encounter at the planning stage, it is proposed to implement SADT. The research demonstrates a breakdown of the original function "Development of the organization's production strategy" based on the SADT diagram, which describes the input-output transformations and the rules for these transformations. So as to confirm the practical applicability of this tool, it was tested in the energy company OOO Gazspetsstroy. Based on the suggested work plan, the activities for the development of the company's production strategy are distributed in accordance with the workload of the working group and the complexity of the work performed.
\end{abstract}

\section{Introduction}

In modern economic climate, Russian companies need effective tools to achieve a competitive advantage. The production decline caused by the global financial crisis had a negative impact on many enterprises in the industrial system. Amid economic malaise, for enterprises, it is not so much survival that is a high priority as promotion of competitiveness, which in turn requires the upgrading of manufacturing systems.

Meanwhile, the management of many enterprises in Russia pays insufficient attention to the problem of developing production strategies and tactics. The measures aimed at rationalization of production quite often start to be implemented not until there is a high chance of bankruptcy. Moreover, the most common way of acting in such situations is to draw on the resources of professional advisers, whose objective is to maintain at least part of the organization's production level. Taking into account the rapidly changing market situation, production diversification, changes in the internal and external environment, the key to company survival and intensification of all manufacturing processes is the development of a production strategy and tactics aimed to improve the production and financial activity by optimizing resource usage of production potential.

Development issues of the production strategy and tactics of an organization require theoretical understanding, appropriate methodological support, new practical approaches

\footnotetext{
*Corresponding author: minnullinaay@yandex.ru
} 
and solutions, taking into account the peculiarities of economic functions and political development in Russia. Modern authors distinguish the following production strategies: the complete satisfaction of demand, the manufacturing at the average demand level, the manufacturing at the lower demand level, the flow production strategy, the strategy of operational management of the production system, the strategy of total quality control, the strategy of flexible production management (lean production), the strategy of business reengineering; the consumer-oriented production strategy, the production location strategy, the manufacturing-engineering strategy, the exact copying strategy (Figure 1) [1-6].

The baseline production strategy implies a balance of capacity of the work force and the factory load [7]. When developing the baseline strategy, the following is taken into account:

- engineering level of the production process and the possibility of upgrading equipment;

- qualification potential and the labor force level of the production;

- the possibility of quick equipment revamping and other necessary actions associated with possible changes in the structure, scope and timing of production orders.

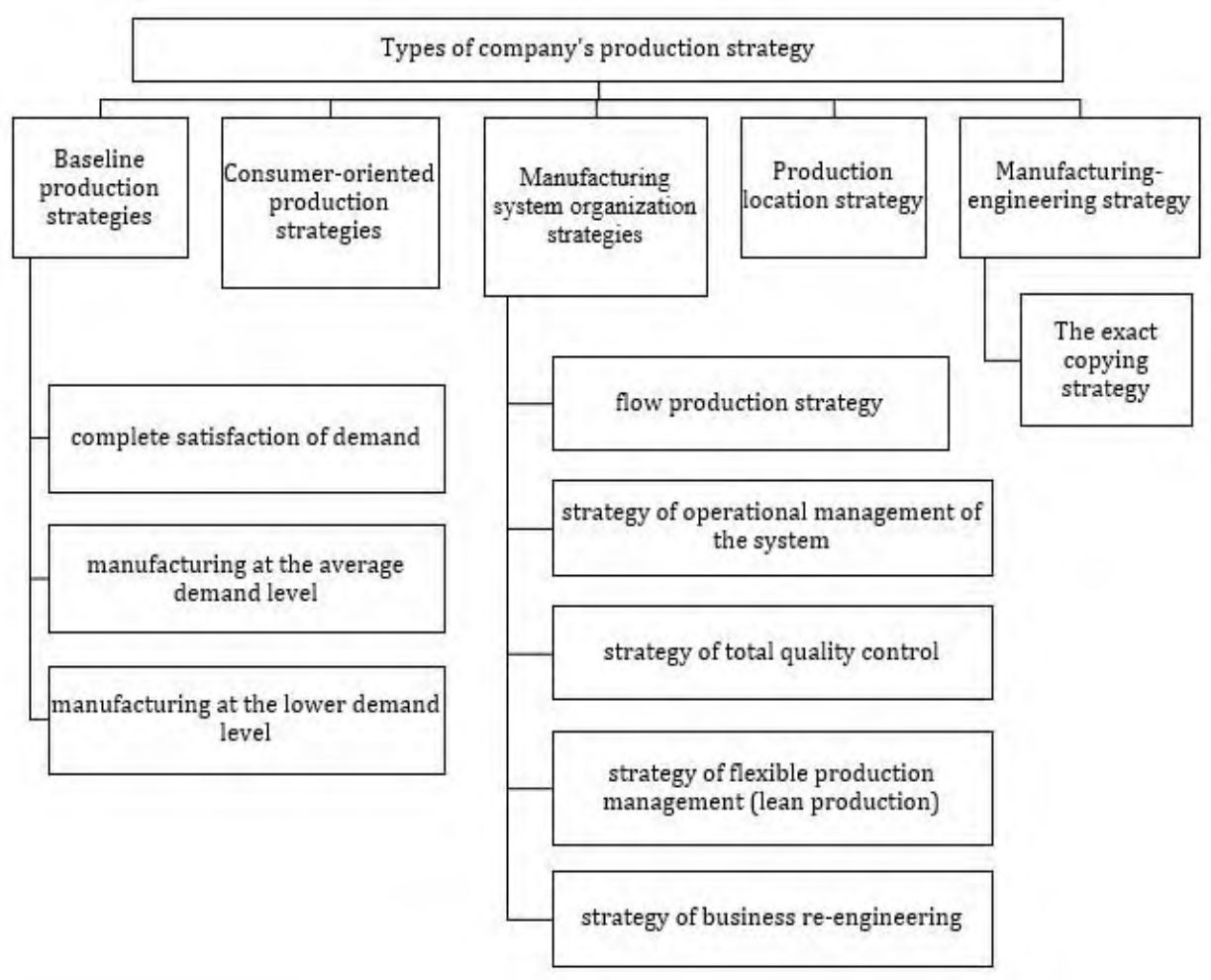

Fig. 1. Modern classification of the major production strategies of a company.

Depending on the existing situation, a company chooses one or several lines of production development, which involve acquisition of new equipment; upgrade of the existing one; orientation on consumer satisfaction performed by introducing a quality indicator at all manufacturing stages; focusing on reduction of time required to complete various operations; introduction of new technologies in order to increase the production competitiveness; industrial personnel training and increasing flexibility of production.

\section{Materials and methods}


The production strategy has complex relationships with other functional strategies of the company and is associated with a variety of environmental factors. In this regard, it is reasonable for a company to form a production strategy development model using SADT (Structural Analysis and Design Technique). Information representation in SADT is an interconnected complex of SADT-diagrams that describe input and output transformations and the transformation rules [8].

Figure 2 displays the breakdown of the original function "Development of the organization's production strategy".

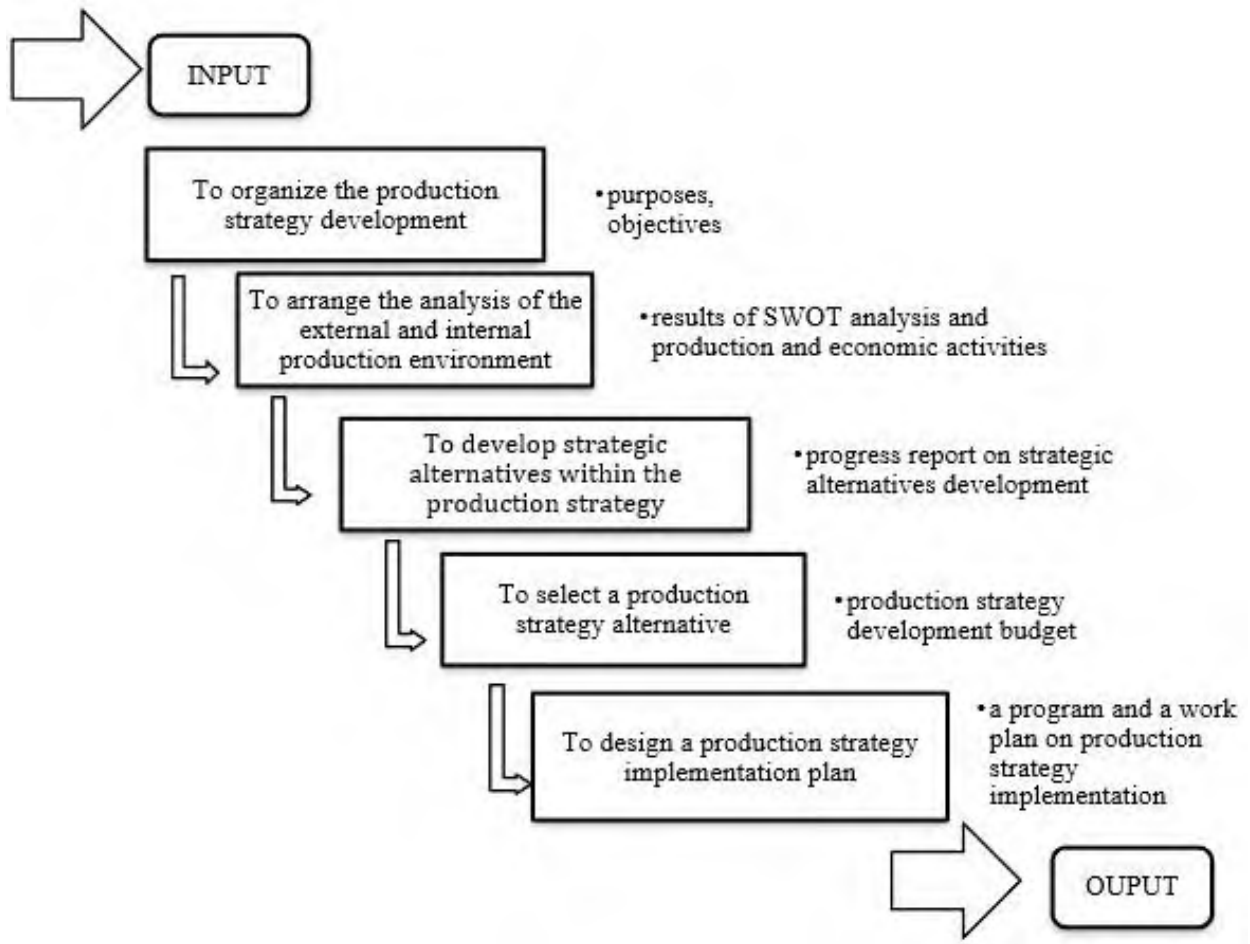

Fig. 2. "Development of the organization's production strategy" based on SADT.

Furthermore, a separate breakdown is developed for each function within the framework of the original "Development of the organization's production strategy". The final output will be a developed work plan for production strategy development.

The algorithm allows to create a special organizational and information environment for making well-founded management decisions based on a qualitative and quantitative assessment of the production potential and capacity of a company.

Each stage requires interaction with various experts. Therefore, for the purpose of organizational support for the production strategy development, a special work group is formed from among qualified specialists of various areas of expertise. The formed work group would allow to comprehensively study and analyze the components of the production strategy. In general terms, the work group model defines the roles and responsibilities of the participants at different development stages, as well as implementation and support of the manufacturing strategy. These functions are interrelated and overlapping, which allows for continuous interaction between the group members. The proposed version of the distribution of responsibilities would make it possible to involve a wide range of experts in the process, as well as to analyze and evaluate various alternative developments of the 
situation and to introduce a further set of measures to design and support the production strategy.

\section{Results}

Before testing and endorsing the suggested recommendations, the analysis of the financial and economic activity of the energy company OOO Gazspetsstroy in the Tyumen region in the Russian Federation, was carried out. The analysis was conducted in order to identify shortcomings in the company's production environment that require separate or complex measures for improvement. The development of a production strategy implies cyclical execution of a number of sequential stages of work on the analysis, assessment, planning of goals and results of the activity for a certain period of time. Moreover, the initial elements of the implementation of the production strategy formation algorithm are organization's assessment of market positions and the objectives of production and economic activities [8]. The production strategy is developed based on the overall strategy of a company, its objectives and mission (table 1).

Table 1. The key guiding principles of the production strategy of OOO Gazspetsstroy.

\begin{tabular}{|c|l|}
\hline $\begin{array}{c}\text { Key guiding } \\
\text { principles }\end{array}$ & \multicolumn{1}{|c|}{ Content of the principles } \\
\hline Mission & $\begin{array}{l}\text { To raise the production of general construction work to a qualitatively new level, } \\
\text { as well as to become a leading construction company in the Tyumen region, } \\
\text { offering high quality construction work and customer service }\end{array}$ \\
\hline Purpose & $\begin{array}{l}\text { To carry out general construction work of high quality due to a unique resource } \\
\text { base, high technology level and a team of professionals }\end{array}$ \\
\hline Objectives & $\begin{array}{l}\text { 1) to apply high-quality effective materials and new technologies in } \\
\text { construction } \\
\text { 2) to implement a flexible pricing system at different construction stages } \\
\text { 3) to conduct permanent quality monitoring of the construction work } \\
\text { performed } \\
\text { 4) to continuously improve qualifications of workers engaged in the building } \\
\text { process }\end{array}$ \\
\hline Components & $\begin{array}{l}\text { 1. Production organization strategy } \\
\text { 3. Development strategy of capacity and technology } \\
\text { 4. Strategy for the production infrastructure development }\end{array}$ \\
\hline
\end{tabular}

Organizational support of manufacturing strategy is a mechanism that allows to effectively implement the strategic directions of company's growth. It is understood that the performance of the management system as a whole and the effectiveness of the production strategy largely depend on the level of this mechanism's adequacy to changes in the external and internal environment. OOO Gazspetsstroy was proposed to implement a specific manufacturing strategy structure, including individual elements that determine the enhancement of quality and productivity of production (Figure 3).

In order to provide organizational support for the production strategy design in OOO Gazspetsstroy, a special work group was formed, from among qualified specialists of various areas of expertise: an economist, chief engineer, head of procurement, a production technology specialist, section head and a director whose competence would include the responsibility to recognize the productivity of the project (Table 2). 


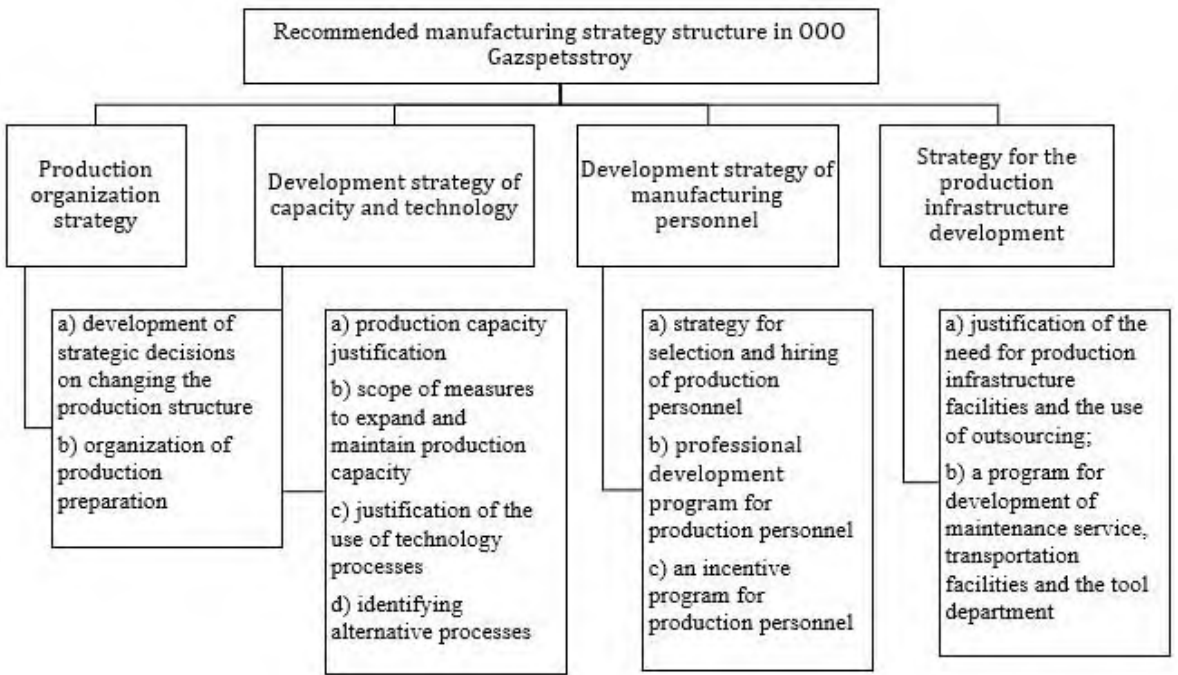

Fig. 3. Production strategy and its components in OOO Gazspetsstroy.

Table 2. Distribution of powers between the employees of the company's work group on the production strategy design.

\begin{tabular}{|c|c|c|c|c|c|c|}
\hline \multirow[b]{2}{*}{ Stages } & \multicolumn{6}{|c|}{ Company employees } \\
\hline & Director & \begin{tabular}{|c|} 
Production \\
technology \\
specialist \\
\end{tabular} & Economist & $\begin{array}{l}\text { Chief } \\
\text { engineer }\end{array}$ & $\begin{array}{l}\text { Head of } \\
\text { procurement }\end{array}$ & $\begin{array}{l}\text { Section } \\
\text { head }\end{array}$ \\
\hline $\begin{array}{l}\text { 1. Diagnostics of the external } \\
\text { manufacturing environment }\end{array}$ & $P$ & E, L & $\mathrm{E}$ & M & M & M \\
\hline $\begin{array}{l}\text { 1. Diagnostics of the internal } \\
\text { manufacturing environment } \\
\text { and congruence of objectives }\end{array}$ & M & E & M & E, L & M & E \\
\hline $\begin{array}{l}\text { 2. Development of strategic } \\
\text { alternatives within the } \\
\text { production strategy: }\end{array}$ & & & & & & \\
\hline $\begin{array}{l}\text { 2.1. Production organization } \\
\text { strategy }\end{array}$ & $\mathrm{R}$ & E & $\mathrm{P}$ & E, L & $\mathrm{P}$ & $\mathrm{P}$ \\
\hline $\begin{array}{l}\text { 2.2. Development strategy of } \\
\text { capacity and technology }\end{array}$ & $\mathrm{R}$ & E, L & $\mathrm{E}$ & M & M & $\mathrm{P}$ \\
\hline $\begin{array}{l}\text { 2.3. Development strategy } \\
\text { of manufacturing personnel }\end{array}$ & $\mathrm{R}$ & $\mathrm{E}$ & $\mathrm{P}$ & E, L & $\mathrm{P}$ & $\mathrm{P}$ \\
\hline $\begin{array}{l}\text { 2.4. Strategy for the } \\
\text { production infrastructure } \\
\text { development }\end{array}$ & $\mathrm{R}$ & $P$ & E, L & $\mathrm{E}$ & M & $\mathrm{P}$ \\
\hline $\begin{array}{l}\text { 3. Calculation of economic } \\
\text { efficiency } \\
\text { of selected production } \\
\text { strategy alternatives }\end{array}$ & $\mathrm{R}$ & M & E, L & M & $\mathrm{P}$ & $\mathrm{P}$ \\
\hline $\begin{array}{l}\text { 4. Control system } \\
\text { development and monitoring } \\
\text { of the manufacturing } \\
\text { strategy implementation }\end{array}$ & $\mathrm{R}$ & $\mathrm{P}$ & M & E, L & $\mathrm{P}$ & $P$ \\
\hline
\end{tabular}

In table 2, the following symbols are adopted for actions and decisions of participants in the manufacturing process [9]:

$\mathrm{P}$ - the employee takes part; 
E - the employee organizes and executes;

$\mathrm{L}$ - the employee is held liable;

$\mathrm{R}$ - the employee approves the results;

$\mathrm{M}$ - an employee monitors the operation;

Table 3. Work plan on development and revision of the production strategy in OOO Gazspetsstroy.

\begin{tabular}{|c|c|c|c|c|c|c|c|c|c|c|c|c|}
\hline \multirow[t]{2}{*}{ Work plan } & \multicolumn{12}{|c|}{ Time period } \\
\hline & Jan. & Feb. & March & Aug. & May & June & July & Aug. & Sept. & Oct. & Nov. & Dec \\
\hline $\begin{array}{l}\text { Task for } \\
\text { development } \\
\text { / revision of } \\
\text { the } \\
\text { production } \\
\text { strategy }\end{array}$ & + & & & & & & & & & & & \\
\hline $\begin{array}{l}\text { Formation of } \\
\text { purposes and } \\
\text { objectives of } \\
\text { production } \\
\text { strategy and } \\
\text { tactics }\end{array}$ & + & & & & & & & & & & & \\
\hline $\begin{array}{l}\text { Formation of } \\
\text { the list } \\
\text { of strategic } \\
\text { alternatives } \\
\text { based on the } \\
\text { analysis of } \\
\text { external and } \\
\text { internal } \\
\text { production } \\
\text { environment }\end{array}$ & & + & + & & & & & & & & & \\
\hline $\begin{array}{l}\text { Assessment } \\
\text { of strategic } \\
\text { alternatives }\end{array}$ & & & + & + & & & & & & & & \\
\hline $\begin{array}{l}\text { Development } \\
\text { / revision of } \\
\text { individual } \\
\text { components } \\
\text { of the } \\
\text { production } \\
\text { strategy }\end{array}$ & & & & + & + & + & & & & & & \\
\hline $\begin{array}{l}\text { Development } \\
\text { / revision and } \\
\text { approval of } \\
\text { designated } \\
\text { program }\end{array}$ & & & & & & & + & & & & & \\
\hline $\begin{array}{l}\text { Strategic } \\
\text { plan design }\end{array}$ & & & & & & & + & + & & & & \\
\hline $\begin{array}{l}\text { Development } \\
\text { of an annual } \\
\text { plan }\end{array}$ & & & & & & & & + & + & & & \\
\hline $\begin{array}{l}\text { Presentation } \\
\text { and approval } \\
\text { of strategic } \\
\text { and annual } \\
\text { plans }\end{array}$ & & & & & & & & & & + & & \\
\hline $\begin{array}{l}\text { Development } \\
\text { of monthly } \\
\text { progress } \\
\text { reports }\end{array}$ & + & + & + & + & + & + & + & + & + & + & + & + \\
\hline
\end{tabular}

The formed work group would allow to comprehensively study and analyze the components of the production strategy. In general terms, the work group model defines the 
roles and responsibilities of the participants at different development stages, as well as implementation and support of the manufacturing strategy. These functions are interrelated and overlapping, which ensures the continuous interaction of group members [10].

The proposed version of the distribution of responsibilities would make it possible to involve a wide range of experts in the process, as well as to analyze and evaluate various alternative developments of the situation and to introduce a further set of measures to design and support the production strategy $[11,12]$. After the determination of the work group and the distribution of powers and responsibilities between production process participants, a work plan for the implementation of the proposed activities is formed (Table $3)[13,14]$. Based on the suggested work plan, the activities for the development of the production strategy of LtD Gazspetsstroy are distributed in accordance with the workload of the working group and the complexity of the work performed.

\section{Conclusions}

As a result, the production strategy development plan allowed OOO Gazspetsstroy to adhere to the time frame, as well as to increase specialists' responsibility and to achieve productive coordination at every stage, which is crucial to meeting both strategic and tactical production development purposes.

It is very important to bear in mind that in order to develop a company's manufacturing strategy, it is necessary to provide shrewd and timely information supply so as to support decision-making at all levels of management. Such information supply includes analytical information in the form of reports summarizing the company's performance for a certain time period, statistics on the company's activities for comparative analysis and forecasting, as well as latest updates on "emergency" situations, the causes of their occurrence and ways of dealing with them.

\section{References}

1. A.D. Sheremet, Finance of enterprises 208 (2008)

2. A.D. Sheremet, M.I. Bakanov, Theory of Economic Analysis 536 (2011)

3. V. Danenburg, Basics wholesale 248 (2003)

4. D. Jobber, Sales and Sales Management 622 (2002)

5. G. Jones, Trading Business: How to Organize and Manage 303 (1996)

6. N. Rekhem, Managing big sales 313 (2003)

7. V.V. Kovalev, V.V. Kovalev, Finance of enterprises 432 (2016)

8. S.V. Eden, Wholesale firms: strategy and development tactics 78 (2003)

9. G.A. Savickaya, Analysis of the economic activity of the enterprise 608 (2017)

10. D. Sichelli, Compensation to Sales Personnel: A Practical Guide to Developing Effective Compensation Programs 230 (2005)

11. V.G. Eliferov, Process Approach to Organization Management http://www.tengrygroup.com/consulting/library

12. N. Zotkina, A. Kopytova, M. Zenkina, O. Zhigunova, MATEC Web of Conferences 106, 08058 (2017) doi: 10.1051/matecconf/201710608058

13. A. Minnullina, R. Abdrazakov, Advances in Intelligent Systems and Computing 692, 1224-1233 (2018) doi: 10.1007/978-3-319-70987-1_131 
14. V.T. Erofeev, T.F. Elchishcheva, N.I. Vatin, E.A. Mitina, A.I. Rodin, I. V. Erofeeva. Industrial and Civil Engineering. 2020. (8). Pp. 4-15. DOI:10.33622/08697019.2020.08.04-15.

15. G. Kozlov, et al. Advances in Intelligent Systems and Computing 676-684 (2020) doi:10.1007/978-3-030-57453-6_64 